\title{
Peanut lectin histochemistry of Barrett's esophagus
}

\author{
Hugh J. Freeman, MD
}

\begin{abstract}
Barrett's epithelium refers to the replacement of the normal stratified squamous epithelium with columnar epithelial cells, possibly as a consequence of chronic reflux of gastric content into the esophagus, and is thought to be a pre-neoplastic disorder with the later development of esophageal adenocarcinoma. In this study, biopsy specimens from patients with Barrett's esophagus were examined with fluorescein-linked peanut lectin to determine if lectin reactivity, indicative of a previously reported colon cancer-associated mucin in colonic polyps, was present in the columnar lined esophagus. In all of the patients studied, positive but variable labelling with this lectin was present, providing additional evidence that Barrett's epithelium represents a heterogeneous preneoplastic change of the esophagus. Can J Gastroenterol 1989;3(5):185-188
\end{abstract}

Key Words: Barrett's esophagus, Carcinogenesis, Esophageal cancer, Glycoproteins, Goblet cells, Lectin histochemistry.

\section{Histochimie de la lectine d'arachide dans la métaplasie de Barrett}

RESUME: La métaplasie de Barrett se décrit comme le remplacement de l'épithélium pavimentaux stratifié normal par un épithélium métaplasique cylindrique, pouvant apparaître à la suite de lésions chroniques d'esophagite peptique; on estime que cet état métaplasique est précancéreux. Dans cette étude, le matériel de biopsie prélevé sur des patients atteints de métaplasie de Barrett est examiné à l'aide de lectine d'arachide liée à la fluorescéine, afin de déterminer si la réactivité de la lectine indiquant la présence de mucine associée au cancer du côlon dans les polypes du côlon, se manifeste également dans le cas de l'épithélium cylindrique. Chez tous les patients étudiés, ces résultats positifs mais variables ont été obtenus. Ce type de lectine fournit la preuve supplémentaire que la métaplasique de Barrett représente un changement pré-néoplastique hétérogène de l'esophage.
Department of Medicine, University Hospital; and the University of British Columbia,

Vancouver, British Columbia

Correspondence and reprints: Dr Hugh Freeman, Head, Gastroenterology, ACU F-137,

University Hospital, University of British Columbia, 2211 Wesbrook Mall, Vancouver, British

Columbia V6T IW5. Telephone (604) 228-7216 or 7235

Received for publication May 7, 1989. Accepted August 4, 1989
$\mathrm{B}$ ARRETT'S ESOPHAGUS IS DEFINED AS one that is lined with columnar epithelium instead of typical stratified squamous epithelium $(1,2)$. It is generally thought that in adults this disease results from chronic or recurrent reflux of gastric content into the esophagus with the progressive replacement of squamous epithelium by columnar epithelium in a cephalad direction. This epithelium has been well characterized using histologi$\mathrm{cal}$ (3), cell kinetic (4), histochemical (5-7) and immunocytochemical methods (8). Esophageal strictures and ulcers are frequently observed complications associated with Barrett's esophagus (2); in addition, adenocarcinoma of the esophagus has been observed ( 9 ) with an estimated prevalence of $8.5 \%$ (10). Current treatment is aimed at preventing gastroesophageal reflux; endoscopic surveillance should be considered because of the potential later development of carcinoma.

Previous studies have explored alterations in gastrointestinal mucins associated with the development of cancer, particularly colonic adenocarcinoma, in chemically induced animal models (11, 12) as well as in human colonic adenomas and carcinomas $(13,14)$. Fluorescent lectins are proteins that appear to identify specific carbohydrate structures on fixed tissue sections; one example is pea- 
nut lectin. Altered labelling of goblet cell mucins with peanut lectin has been reported as a cancer-associated mucin change in benign colonic polyps, which are precancerous lesions in the human colon (14). As Barrett's esophagus is purported to be a pre-neoplastic disorder of the esophagus (9), this study examined mucosal biopsies in a series of patients with Barrett's esophagus to determine if labelling with this lectin was present.

\section{PATIENTS AND METHODS}

Patients and biopsies: A total of 125 endoscopic esophageal biopsies were examined from 22 patients including 13 males and nine females seen over a two year period. The number of biopsies and clinical details from each patient are summarized in Table 1. The majority of patients $(86 \%)$ were more than 50 years old. Most had radiographic and endoscopic evidence of esophageal stricture (64\%). One patient (case 19) had a total gastrectomy with esophagojejunostomy for gastric antral adenocarcinoma, and subsequently developed stricture proximal to the surgical anastomosis. A second patient (case 3) had radiotherapy for squamous cell carcinoma of the esophagus. A third (case 9) had a coexistent colloid carcinoma of the esophagogastric junction. The clinical details of these 22 patients were previously defined (8). All endoscopic biopsies were obtained under direct vision from the esophagus with an Olympus fibreoptic gastroscope between 20 and $35 \mathrm{~cm}$ from the incisor teeth. Each biopsy was routinely fixed and processed, embedded in paraffin and serially sectioned at $5 \mu \mathrm{m}$. Serial sections were also examined by routine light microscopy following staining with hematoxylin and eosin, periodic acid-Schiff reagent and alcian blue, $\mathrm{pH} 2.5$. Only biopsies positive to periodic acid-Schiff reagent were examined, and these were classified as specialized columnar type if the surface epithelium stained blue with alcian blue.

Lectin labelling: Deparaffinization, sequential washes in 95,80 and $70 \%$ alcohols to $0.01 \mathrm{M}$ phosphate buffered saline, $\mathrm{pH} 7.4$, was followed by lectin labelling as previously described (15). Fluorescein isothiocyanate conjugated peanut lectin
TABLE 1

Patients with Barrett's esophagus

\begin{tabular}{|c|c|c|c|c|}
\hline $\begin{array}{l}\text { Patient } \\
\text { number * }\end{array}$ & Age & Sex & Stricture & $\begin{array}{l}\text { Specialized } \\
\text { columnar }\end{array}$ \\
\hline $1(6)$ & 58 & Male & Yes & \\
\hline $2(3)$ & 89 & Male & Yes & + \\
\hline $3(9)$ & 54 & Male & Yest & - \\
\hline $4(4)$ & 26 & Female & No & + \\
\hline $5(8)$ & 66 & Male & Yes & + \\
\hline $6(3)$ & 70 & Male & Yes & + \\
\hline $7(5)$ & 62 & Male & Yes & + \\
\hline $8(9)$ & 74 & Female & Yes & - \\
\hline $9(4)$ & 41 & Male & Yesł & - \\
\hline $10(3)$ & 84 & Male & No & . \\
\hline $11(4)$ & 51 & Female & No & \\
\hline $12(7)$ & 70 & Male & No & + \\
\hline $13(10)$ & 57 & Female & Yes & + \\
\hline $14(7)$ & 59 & Female & Yes & + \\
\hline $15(3)$ & 86 & Male & No & - \\
\hline $16(7)$ & 58 & Female & Yes & - \\
\hline $17(3)$ & 18 & Fernale & No & - \\
\hline $18(3)$ & 52 & Female & No & + \\
\hline $19(9)$ & 83 & Male & Yes ${ }^{\S}$ & + \\
\hline $20(9)$ & 88 & Female & Yes & - \\
\hline $21(4)$ & 70 & Male & No & . \\
\hline $22(5)$ & 62 & Male & Yes & + \\
\hline
\end{tabular}

- Number in parentheses indicates total number of esophageal biopsies examined; $†$ Previous squamous cell carcinoma esophagus treated with radiotherapy five years earlier: $\ddagger$ Colloid type adenocarcinoma involving esophagogastric junction: \$ Previous gastric antral adenocarcinoma followed by total gastrectomy and esophagojejunostomy
(FITC-PNA) derived from Arachis hypogaea (Vector Laboratories, Burlingame, California) was used as previously described (15). A solution of the same lectin concentration containing the sugar hap-

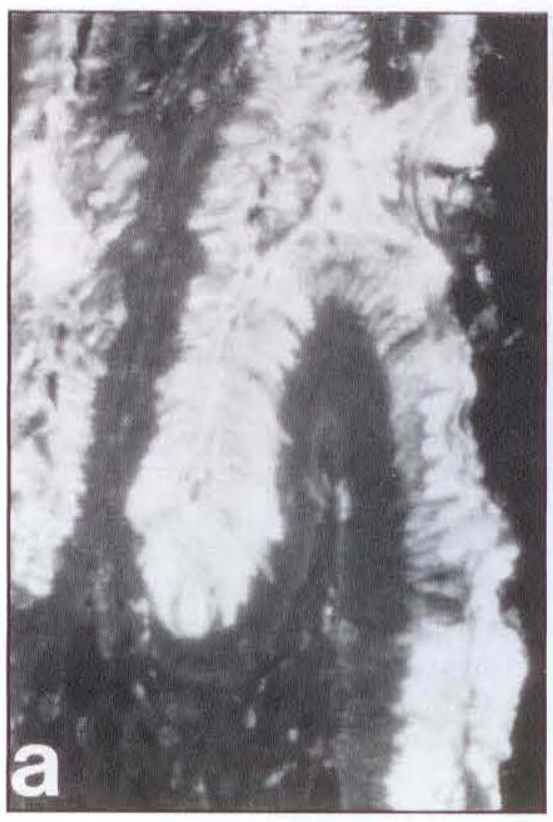

ten inhibitor, D-galactose, at a concentration of $0.3 \mathrm{M}$ was used on adjacent control sections (15). Following preparation, observations were recorded using a Zeiss epifluorescence photomicroscope.

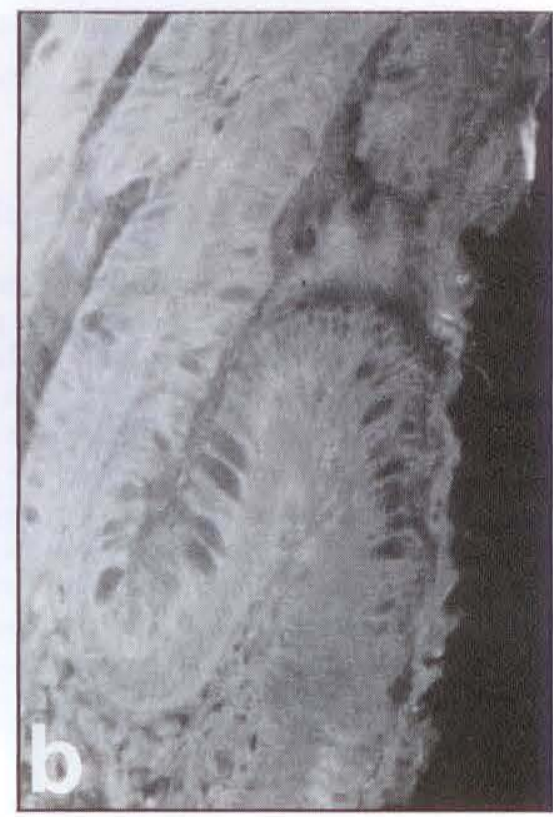

Figure 1) Left FITC-PNA labelling of an endoscopic esophageal biopsy from a patient with Barrett's esophagus. Fluorescence is localized primarily to the supranuclear region of the epithelial cells. Exposure 60 s. Right An adjacent section from the same biopsy is labelled with FITC-PNA and the inhibitor, $0.3 \mathrm{M}$ galactose; labelling is absent despite intentional overexposure with epifluorescence. Exposure $90 \mathrm{~s}$ 


\section{RESULTS}

All of the patients in this study had esophageal biopsies that stained positively with FITC-PNA. Including patients with specialized columnar epithelium in the esophagus, the surface epithelium and/or underlying glandular epithelium were labelled with FITC-PNA. Adjacent control sections with the inhibitor sugar were uniformly negative (Figure 1). The degree of labelling, as reflected in the intensity of fluorescence, was variable, even in the same biopsy sections (Figure 2). Although labelling appeared to localize to mucus primarily in the supranuclear regions within the epithelial cells, some, often adjacent, goblet cells in the same endoscopic biopsies were weakly labelled or failed to label (Figure 3). In some biopsies, mucus associated with the luminal membrane of the surface epithelium was also labelled (Figure 4), but it was not pos- sible in this study to determine if this fluorescence was due to secreted and adherent mucus or, in part, to exposed sugars on the epithelial cell luminal membrane.

\section{DISCUSSION}

Prior studies using a variety of histological (3), histochemical (5-7) and immunocytochemical techniques (8) have demonstrated that mucosal biopsies from patients with Barrett's esophagus represent a morphological epithelial mosaic apparently in response to chronic reflux of gastric content into the esophagus. This study of a series of patients with Barrett's esophagus using a specific fluorescein-linked lectin, peanut agglutinin, revealed positive labelling in all patients similar to positive peanut lectin reactivity of goblet cell mucins reported previously in benign and malignant neoplastic colonic disease $(13,14)$.
Although positive lectin staining was present in all patients, no differences were seen in Barrett's epithelium of patients with or without different types of cancer. This suggests that the epithelial mucins in Barrett's epithelium are altered or incompletely glycosylated, this being possibly related to abnormal or impaired epithelium differentiation. All of the biopsies used in this study, however, were examined in a retrospective manner. A prospective study in Barrett's patients with later cancer development is necessary to define the usefulness of these observations in biopsy surveillance and the detection of precancerous change, and chronological or sequential study is required prior to the development of frank carcinoma to define the value of biopsy surveillance in clinical practice. In addition, the natural history of this mucin change, the effects of therapy and its reversibility deserve careful evalua-
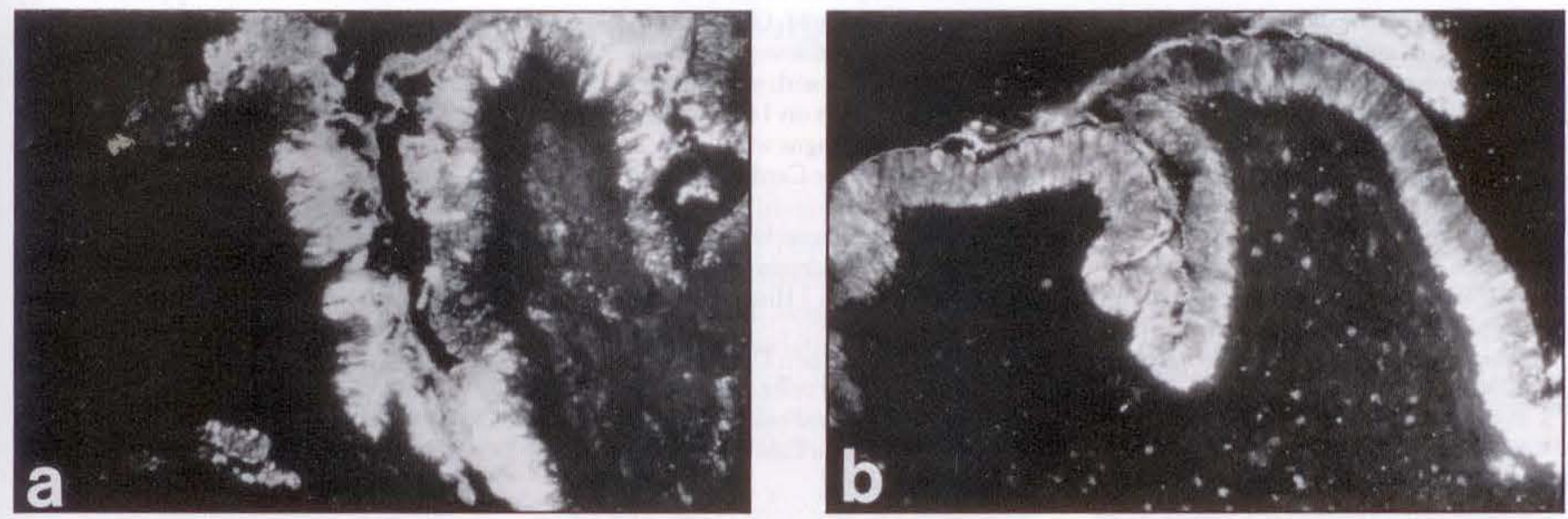

Figure 2) Variable FITC-PNA labelling of the surface epithelium in the same endoscopic biopsies obtained from two different patients. Exposure 60 s

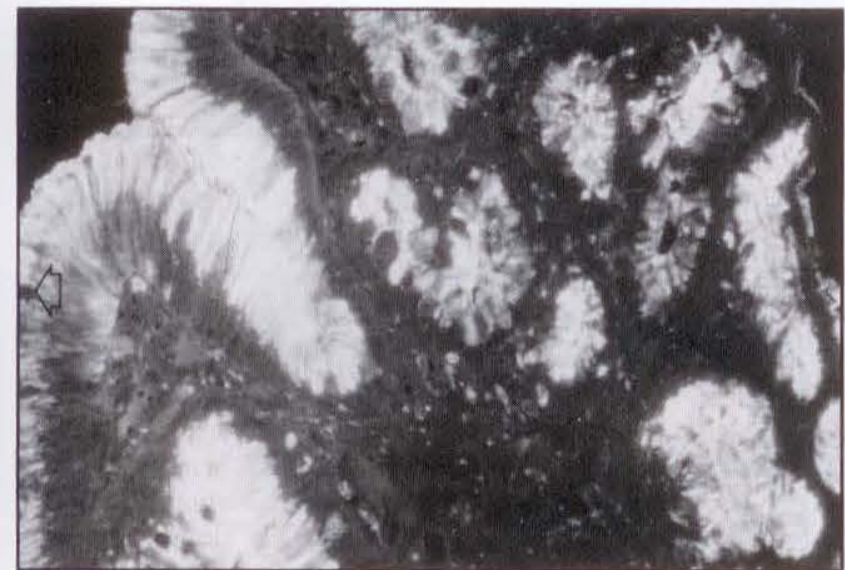

Figure 3) Variable FITC-PNA labelling of goblet cell mucins (arrows). For some cells, labelling is absent. Exposure $60 \mathrm{~s}$

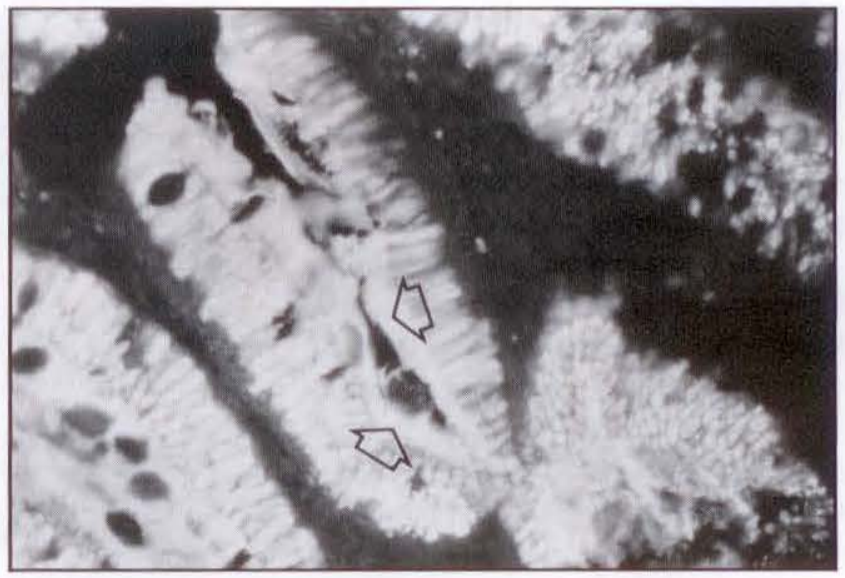

Figure 4) FITC-PNA labelling showing positive fluorescence in the epithelial cells and luminal mucins (arrows). Exposure $60 \mathrm{~s}$ 
tion. Prior studies (16-19) have also explored in detail the pattern of lectin binding to normal and pathological gastric mucosa, including intestinal metaplasia and gastric cancer; epithelial mucus was characterized by an absence of peanut lectin binding but strong binding to poorly differentiated cells was reported (19). Although not entirely novel, studies of the gastric mucosa in Barrett's esophagus might also be examined.

Although all of the patients in this study were positive, the variable nature of lectin labelling for individual epithe-

ACKNOWLEDGEMENTS: This work was supported by a research grant from the Vancouver Foundation.

\section{REFERENCES}

1. Barrett NR. Chronic peptic ulcer of the oesophagus and 'oesophagitis'. Br J Surg 1950;38:175-82.

2. Trier S. Morphology of the epithelium of the distal esophagus in patients with midesophageal peptic strictures. Gastroenterology 1970; 58:444-61.

3. Paull A, Trier S, Dalton MD, Camp RC, Loe P, Goyal RK. The histologic spectrum of Barrett's esophagus. N Engl J Med 1976;295:476-80.

4. Herbst JJ, Berenson MM, McCloskey DW, Wiser WC. Cell proliferation in esophageal columnar epithelium (Barrett's esophagus). Gastroenterology 1978;75:683-7.

5. Peuchmaur M, Potet F, Goldfain D. Mucin histochemistry of the columnar epithelium of the oesophagus (Barrett's esophagus): A prospective biopsy study. J Clin Pathol 1984;37:607-10.

6. Lee RG. Mucins in Barrett's esophagus: A histochemical study. Am J Clin Pathol 1984;81:500-3.

7. Shimamoto C, Weinstein WM, Boland lial cells, even in the same biopsy sections under identical labelling conditions, implies that there are significant differences in goblet cell mucin reactivity, lending further support to the concept that Barrett's esophagus is a very heterogeneous mucosal disorder. Previous studies in this group of patient biopsies (8) using a cytochemical silver staining technique as well as fluorescence and peroxidaseantiperoxidase single and double staining immunocy tochemical methods, have demonstrated significant differences in the peptide-containing cell types of

CR. Glycoconjugate expression in normal, metaplastic and neoplastic human upper gastrointestinal mucosa. J Clin Invest 1987:80:1670-8.

8. Buchan AMJ, Grant S, Freeman HJ. Regulatory peptides in Barrett's oesophagus. J Pathol 1985;146:227-34.

9. Li ZW, Wensel R, Thomson ABR Barrett's esophagus and adenocarcinoma. Can J Gastroenterol 1988;2:75-8

10. Naef AP, Savary M, Ozzello L. Columnar-lined lower esophagus: An acquired lesion with malignant predisposition. Report on 140 cases of Barrett's esophagus with 12 adenocarcinomas. J Thorac Cardiovasc Surg 1975;70:826-35.

11. Freeman HJ. Lectin histochemistry of 1,2-dimethylhydrazine-induced rat colon neoplasia. J Histochem Cytochem 1983;31:1241-5.

12. Boland CR, Ahnen DJ. Binding of lectins to goblet cell mucin in malignant and premalignant colonic epithelium in the CF-1 mouse. Gastroenterology 1985;89:127-37.

13. Boland CR, Montgomery CK, Kim YS. Alterations in human colonic mucin occurring with cellular differentiation and malignant transformation. Proc Natl Acad Sci USA 1982;79:2051-5.

14. Boland CR, Montgomery CK, Kim YS.
Barrett's mucosa, consistent with the findings in the present study of epithelial and mucosal heterogeneity in Barrett's mucosa. Studies with other lectins or monoclonal antibodies directed towards specific epithelial mucin antigens or receptors might allow further localization of these epithelial mucin or membrane structures in Barrett's esophagus. This approach may permit more detailed examination of specific epithelial carbohydrate structures not generally available with other biochemical or immunological methods.

A cancer-associated mucin alteration in benign colonic polyps. Gastroenterology 1982;82:664-72.

15. Freeman HJ, Lotan R, Kim YS.

Application of lectins for detection of goblet cell glycoconjugate differences in proximal and distal colon of the rat. Lab Invest 1980;43:405-12.

16. Ito M, Takata K, Saito S, Aoyagi T, Hirano $H$. Lectin-binding pattern in normal human gastric mucosa. A light and electron microscopic study. Histochemistry 1985;83:189-93.

17. Albedi FM, Barsotti P, Mingazzini P, Marinozzi V. Visualization of the secretory canaliculi of human parietal cells with a peroxidase-labelled peanut lectin. Light and electron microscopic observations. Cell Tissue Res 1985;239:447-50.

18. Kessimian N, Langner BJ, McMillan PN, Jauregui HO. Lectin binding to parietal cells of human gastric mucosa. J Histochem Cytochem 1986;34:237-43.

19. Fischer J, Klein PJ, Vierbuchen M, Skutta B, Uhlenbruck G, Fischer R Characterization of glycoconjugates of human gastrointestinal mucosa by lectins. I. Histochemical distribution of lectin binding sites in normal alimentary tract as well as in benign and malignant gastric neoplasms. J Histochem Cytochem 1984:32:681-9. 


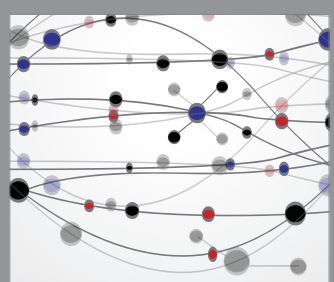

The Scientific World Journal
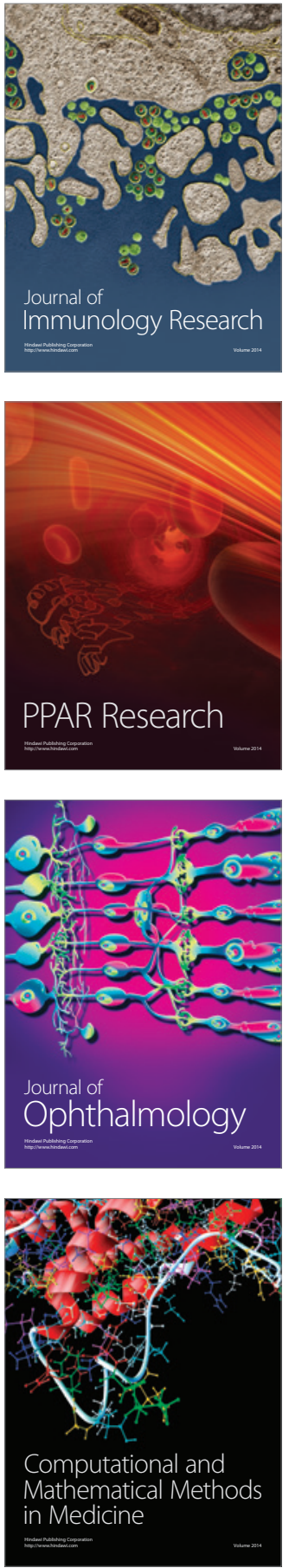

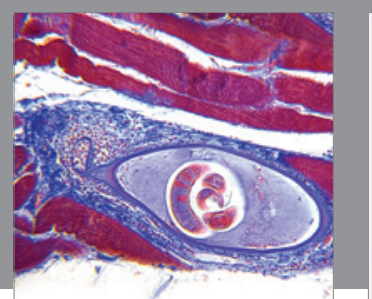

Gastroenterology Research and Practice

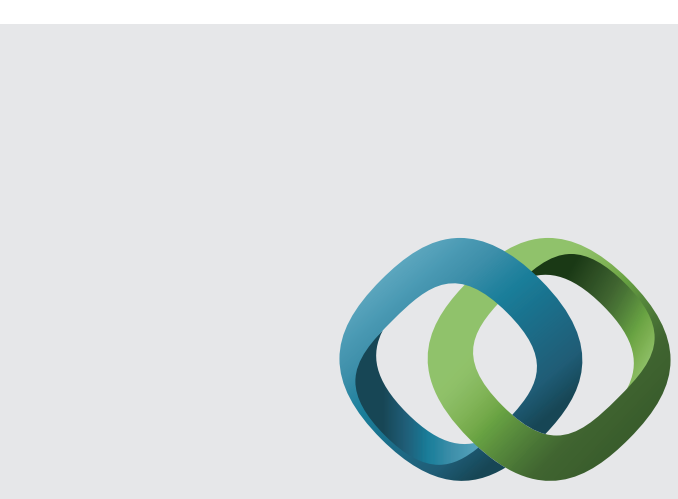

\section{Hindawi}

Submit your manuscripts at

http://www.hindawi.com
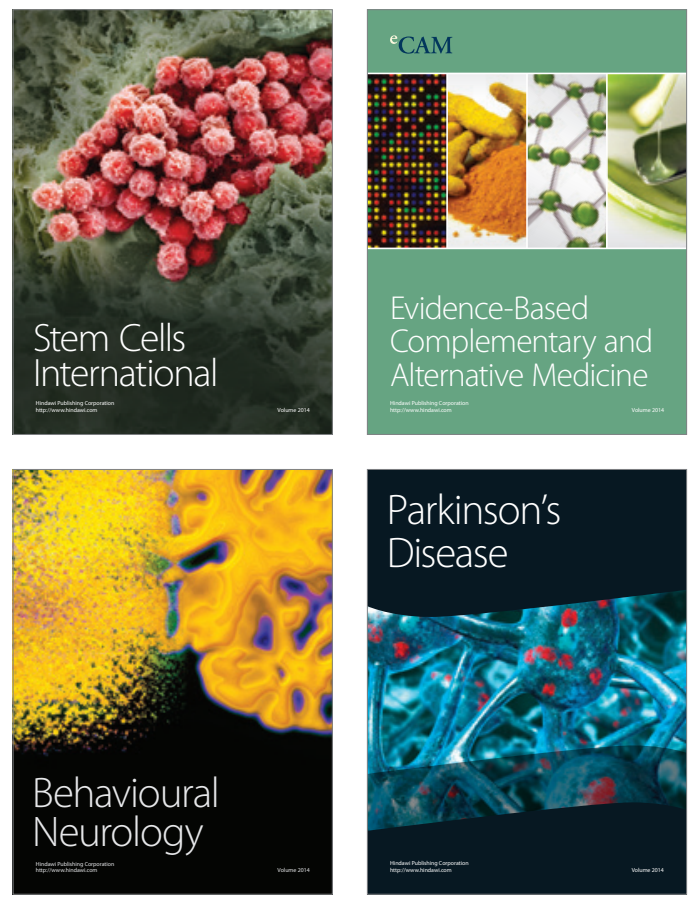
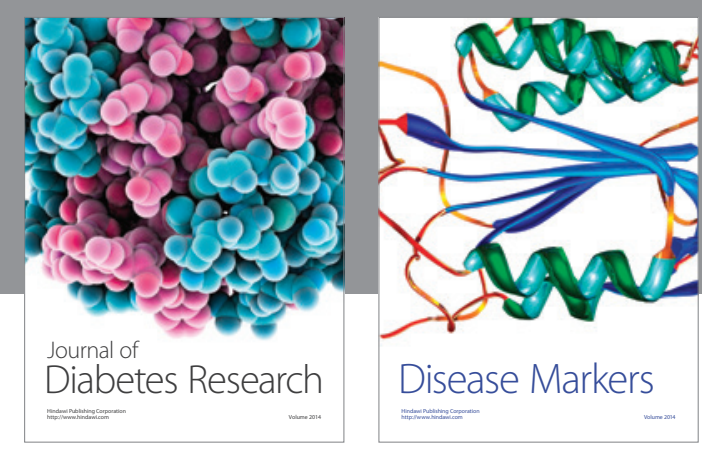

Disease Markers
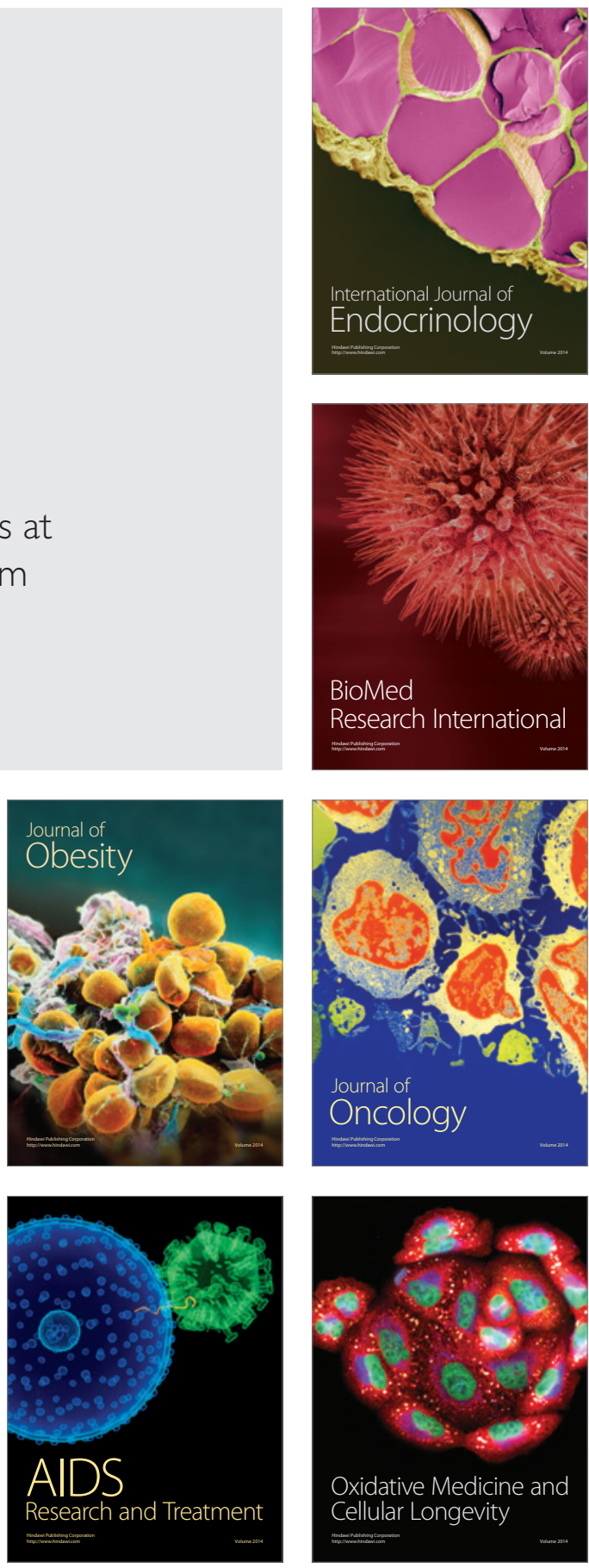